Short Communication

\title{
Piezoelectric Immunosensor for Tissue Transglutaminase Antibodies Determination for Celiac Disease Diagnostic and Comparison with ELISA Method
}

\author{
Adam Kostelnik, Pavla Martinkova, Tomas Valek, Miroslav Pohanka* \\ Faculty of Military Health Sciences, University of Defence, Trebesska 1575, 50001 Hradec Kralove, \\ Czech Republic \\ *E-mail: miroslav.pohanka@gmail.com
}

doi: $10.20964 / 2020.06 .36$

Received: 3 February 2020 / Accepted: 8 March 2020 / Published: 10 May 2020

\begin{abstract}
Celiac disease (CD) is a hereditary disease characterized by occurrence of IgA class antibodies against tissue transglutaminase (anti-tTG) in serum. In this work, we compared standard Enzyme-Linked Immunosorbent Assay (ELISA) with a quartz crystal microbalance (QCM) measuring system for determination of anti-tTG. The new immunosensor is based on immobilized tTG in an open conformation (open-tTG) and optimized for assay of IgA anti-tTG with limit of detection $13.3 \mathrm{RU} / \mathrm{ml}$ and good specificity and stability over time. Testing serum samples of patients suffering CD showed suitability of the prepared immunosensor for practical performance. Compare to ELISA requiring skilled personnel and expensive equipment, the newly constructed measuring system for measurement of QCM sensor is cheap, easy to prepare and does not require any special skill thus it can be introduced into any laboratory or general practitioner office.
\end{abstract}

Keywords: Celiac disease; immunosensor; piezoelectric sensor; IgA antibodies; human tissue transglutaminase

\section{FULL TEXT}

(C) 2020 The Authors. Published by ESG (www.electrochemsci.org). This article is an open access article distributed under the terms and conditions of the Creative Commons Attribution license (http://creativecommons.org/licenses/by/4.0/). 